\title{
Questes
}

\section{Les bruits de la ville : éléments de bibliographie}

\section{Andrea Martignoni et Mickaël Wilmart}

\section{(2) OpenEdition}

\section{Journals}

\section{Édition électronique}

URL : http://journals.openedition.org/questes/2357

DOI : 10.4000/questes.2357

ISSN : 2109-9472

\section{Éditeur}

Les Amis de Questes

\section{Édition imprimée}

Date de publication : 15 mars 2003

Pagination : 17-19

ISSN : 2102-7188

\section{Référence électronique}

Andrea Martignoni et Mickaël Wilmart, «Les bruits de la ville : éléments de bibliographie », Questes [En ligne], 3 | 2003, mis en ligne le 01 janvier 2014, consulté le 19 septembre 2020. URL : http:// journals.openedition.org/questes/2357 ; DOI : https://doi.org/10.4000/questes.2357

Ce document a été généré automatiquement le 19 septembre 2020.

(c) Association des amis de «Questes » 


\title{
Les bruits de la ville : éléments de bibliographie
}

\author{
Andrea Martignoni et Mickaël Wilmart
}

\section{NOTE DE L'ÉDITEUR}

Cet article n'a pas encore fait l'objet d'une autorisation de publication.

INDEX

Keywords : noise, city, sound, shout, scream, rumour, bell, charivari, music

Mots-clés : bruit, ville, son, cri, rumeur, cloche, charivari, musique 